九州大学学術情報リポジトリ

Kyushu University Institutional Repository

\title{
Studies on the Vigour of Soybean Seeds : I. Varietal Differences in Seed Vigour
}

Mugnisjah, Wahju Qamara

Laboratory of Crop Science, Faculty of Agriculture Kyushu University

Shimano, Itaru

Laboratory of Crop Science, Faculty of Agriculture Kyushu University

Matsumoto, Shigeo

Laboratory of Crop Science, Faculty of Agriculture Kyushu University

https://doi.org/10.5109/23845

出版情報: 九州大学大学院農学研究院紀要. 31 (3)，pp.213-226，1987-03-10. Kyushu University バージョン：

権利関係 : 


\title{
Studies on the Vigour of Soybean Seeds I. Varietal Differences in Seed Vigour
}

\author{
Wahju Qamara Mugnisjah, Itaru Shimano and Shigeo Matsumoto \\ Laboratory of Crop Science, Faculty of Agriculture \\ Kyushu University, Fukuoka 812
}

(Received July 31, 1986)

\begin{abstract}
The association of flowering, growth period, reproductive growth period, seed size, the occurrence of defective seed and seed coat colour with varietal differences in seed vigour were investigated using 38 late maturing cultivars originating from Indonesia, America and Japan under the climatic condition of Fukuoka City. The results show that varietal differences in seed vigour were clearly demonstrated by standard germination after 6 days of accelerated ageing at $40^{\circ} \mathrm{C}, 100 \% \mathrm{RH}$ (ranged from 2.7 to $98.7 \%$ ) although their seed viability ranged narrowly (from 76.0 to $100 \%$ ). The genotypical traits, except flowering and growth period, in question were associated with varietal differences in seed vigour as a single factor, respectively. It was also revealed that the climatic condition of middle autumn (daily mean temperature was $15^{\circ} \mathrm{C}$ and total rainfall was $5.5 \mathrm{~mm}$ from 1 to 10 November 1983) facilitated the highest vigour of resulting seeds. Field weathering by high temperature and rainfall in early autumn, and a possible occurrence of cold injury in late autumn lowered the seed vigour. Excluding seed coat colour, a stepwise regression analysis resulted in predominant contribution of seed size, showing negative correlation on varietal differences in seed vigour in terms of standard germination. In terms of electrical conductivity, however, the varietal differences in seed vigour were particularly controlled by reproductive growth period and the occurrence of defective seed. As far as other factors were almost at the same level, the genotypes with black seed coat colour were more vigorous than those with light seed coat colour.
\end{abstract}

\section{INTRODUCTION}

Previous reports regarding varietal differences in seed vigour of soybean were especially concerned with seed characteristics including seed size (Igita and Iwata, 1977 ; Wien and Kueneman, 1981; Minor and Paschal, 1982 ; Dassou and Kueneman, 1984), seed coat colour (Wien and Kueneman, 1981; Dassou and Kueneman, 1984) and hardseededness (Potts et al , 1978 ; Minor and Paschal, 1982 ; Dassou and Kueneman, 1984), but no report concerned with a possibie association of the occurrence of defective seed. Igita and Iwata (1977) paid attention to the association of growth characteristics of mother plant and environmental temperature during their reproductive growth period, but did not to rainfall during this period. These previous studies differed from each other in their methodologies and materials used as their objectives were also different. Therefore, it is obvious that there was not previous study simultaneously analyzed a possible association of aforesaid genotypical factors to varietal differences in seed vigour of soybeans. 
The objective of present study was to investigate the association of flowering (number of days from seeding to flowering date), growth period (number of days from seeding to harvest date), reproductive growth period (number of days from flowering to harvest date), seed size (100-seed weight), the occurrence of defective seed and seed coat colour with varietal differences in seed vigour of soybeans.

\section{MATERIALS AND METHODS}

\section{Seed procurement}

Late maturing soybeans, shown in Table 1, numbering as much as 38 cultivars originating from Japan (6 cultivars), America (22 cultivars) and Indonesia (10 cultivars) were sown in paper pots containing vermiculite on 1 July 1983 and transplanted to the converted rice paddy field on 9 July. Spacing was $70 \times 15 \mathrm{~cm}$ with $20-30$ hills for each cultivar. As basic fertilizer, 1t Mamekasei (3-10-10)/ha, 5t barnyard manure/ha and 1t lime/ha were applied before planting.

The plants were harvested at full maturity stage (Fehr and Caviness, 1977) and were dried outdoor with precaution against direct sun heating or being rained. Seed threshing and cleaning were done by hand followed by storing the seeds in $10^{\circ} \mathrm{C}$ room until their vigour testing was conducted in February-April 1984.

\section{Seed viability and vigour test methods}

Accelerated ageing test as proposed by Delouche and Baskin (1973) for predicting the storability of seed lot and since then modified by Baskin (1981) for soybean was used in the present study. Twenty-five or 50 seeds in $9 \times 10 \mathrm{~cm}$ paper bags were exposed to $40^{\circ} \mathrm{C}, 100 \% \mathrm{RH}$ for 0 (as seed viability) and $4,6,7$ or 8 days (as seed vigour) preceeding to germination and electrical conductiviy tests. The paper bags were arranged on wire tray suspended over plastic box containing 71 . water in a $40^{\circ} \mathrm{C}$ incubator.

\section{Evaluation of seed vigour}

(1) Germination test

Three replicates of 50 seeds were germinated in uprolled filter paper wrapped with plastic film in $25^{\circ} \mathrm{C}$ germinator and the evaluation was made for the following parameters : Maximum growth potential (MGP), germination capacity (GC), standard germination (StG), germination rate (GR), abnormal seedling (Abn), ungerminable-not hard seed (Dead) and hard seed. The method of evaluation and computation of each parameter were those previously described by Mugnisjah and Nakamura (1984). Criteria of normal seedling were as outlined by ISTA (1976), but our evaluation was made regardless of secondary root development.

(2) Electrical conductivity test

Two replicates of 25 seeds were preconditioned on wet filter paper in $9 \times 1.5 \mathrm{~cm}$ Petri-dish at $5^{\circ} \mathrm{C}$ for $24 \mathrm{~h}$ followed by soaking in $100 \mathrm{ml}$ deionized water at $20^{\circ} \mathrm{C}$ for 24 $\mathrm{h}$ prior to the measurement of electrical conductivity of seed leakage.

\section{Climatic data}

Accumulative daily mean temperature and accumulative daily rainfall during 


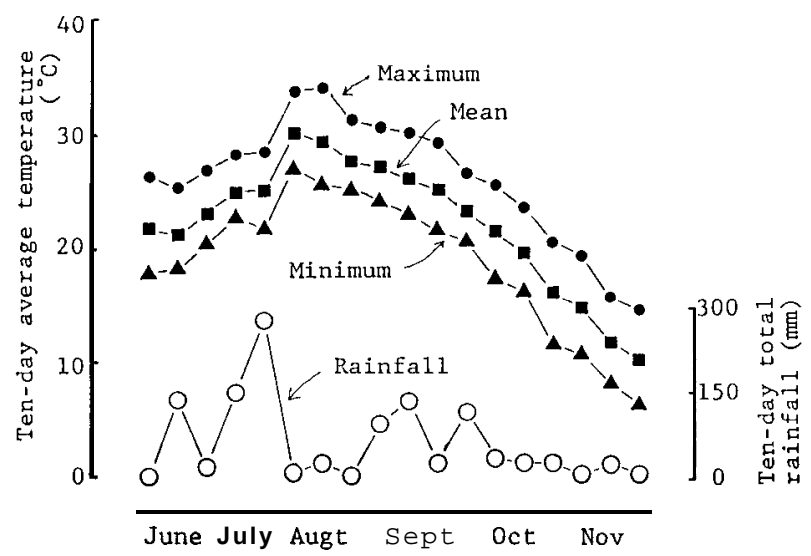

Fig. 1. Climatic conditions in 1983.

reproductive growth period of mother plants were computed using the data provided by Fukuoka City Meteorological Agency. Fig. 1 shows the climatic conditions in 1983.

\section{RESULTS AND DISCUSSION}

1. Effectiveness of accelerated ageing test and sensitivity of seed vigour parameters

The characteristics of 38 cultivars used are shown in Table 1 . Since 28 cultivars marked in that table had complete data at all accelerated ageing, those 28 cultivars were used to justify the effectiveness of accelerated ageing and the sensitivity of seed vigour parameters used.

Table 2 shows the means and standard deviations of electrical conductivity and germination performance resulted from accelerated ageing treatments. Changes in each parameter over control ( 0 day of accelerated ageing) during accelerated ageing are presented in Fig. 2. This figure illustrates decrease in changes of GR, StG, GC and MGP and increase in changes of EC by the treatments. As shown in Table 2 and Fig. 2, 4 days of accelerated ageing was unacceptable for seed vigour evaluation since it failed to deteriorate the seeds and to indicate the proper ranges of standard deviations. Negative change in some parameters showed that this treatment invigourated some cultivars. Similarly, accelerated ageing for 7 or 8 days was ineffective for evaluating seed vigour differences as they were too detrimental, resulting in the occurrence of many dead seeds and abnormal seedlings.

Standard deviation of parameters at 6 days of accelerated ageing ranged between those achieved at 4 and 7 days of accelerated ageing (Table 2). This indicated that the 6 days of accelerated ageing was more appropriate for evaluating seed vigour than the other periods. Fig. 2 demonstrates different magnitude of change among parameters by this treatment ; EC being the highest of all followed by $\mathrm{StG}$, which was the highest among the germination performance. Since such change is important in seed vigour evaluation (TeKrony et al., 1980), 6 days of accelerated ageing was considered to be 
Table 1. Characteristics of soybean cultivars produced in 1983

\begin{tabular}{|c|c|c|c|c|c|c|c|c|c|}
\hline \multirow[b]{2}{*}{ No Cultivar } & \multirow{2}{*}{$\begin{array}{c}\text { Flowering } \\
\text { date }\end{array}$} & \multirow{2}{*}{$\begin{array}{l}\text { Harvest } \\
\text { date }\end{array}$} & \multirow{2}{*}{$\begin{array}{c}\text { Seed } \\
\text { colour" }\end{array}$} & \multirow{2}{*}{$\begin{array}{c}100-\text { seed } \\
\text { weight } \\
(\mathrm{g})\end{array}$} & \multirow{2}{*}{$\begin{array}{c}\text { Coat } \\
\text { defect } \\
(\%)\end{array}$} & \multicolumn{2}{|c|}{ Seed viability } & \multicolumn{2}{|c|}{ Seed vigour ${ }^{11}$} \\
\hline & & & & & & $\begin{array}{c}\mathrm{StG} \\
(\%)\end{array}$ & $\begin{array}{c}\mathrm{EC} \\
(\mu \mathrm{S} / \mathrm{cm} / \mathrm{g})\end{array}$ & $\begin{array}{l}\mathrm{StG} \\
(\%)\end{array}$ & $\frac{\mathrm{EC}}{(\mu \mathrm{S} / \mathrm{cm} / \mathrm{g})}$ \\
\hline \multicolumn{10}{|l|}{ Indonesian soybeans } \\
\hline 1. Nganjuk I* ${ }^{3)}$ & $7 / 9$ & $10 / 11$ & $\operatorname{yg}(b r)$ & 9.35 & 0 & 100 & 36.18 & 96.7 & 44.54 \\
\hline 2. Longgepak* & $16 / 9$ & $10 / 11$ & $g(b r)$ & 7.16 & 0 & 100 & 41.10 & 96.7 & 56.55 \\
\hline 3. Empyek (Jember 1/2)* & $16 / 9$ & $16 / 11$ & $y(b r)$ & 8.48 & 0 & 100 & 37.67 & 92.7 & 44.52 \\
\hline 4.Logel & $11 / 9$ & $10 / 11$ & $\mathrm{~g}(\mathrm{br})$ & 7.68 & 1 & 100 & 41.33 & 97.3 & 47.54 \\
\hline 5. Mojosari ${ }^{*}$ & $16 / 9$ & $21 / 11$ & $g(b r)$ & 8.53 & 0 & 100 & 38.82 & 74.7 & 71.93 \\
\hline 6. Presi Ulung* & $11 / 9$ & $10 / 11$ & $\mathrm{~g}(\mathrm{br})$ & 9.02 & 1 & 98.7 & 34.00 & 96.0 & 38.78 \\
\hline 7. Presi Ulung I* & $11 / 9$ & $21 / 11$ & $y g(b r)$ & 10.31 & 0 & 98.7 & 34.60 & 98.0 & 35.82 \\
\hline 8. Pagak I/2 & $16 / 9$ & $21 / 11$ & $\mathrm{y}(\mathrm{br})$ & 8.93 & 0 & 99.3 & 41.26 & 92.0 & 43.35 \\
\hline 9.Pagak I/3* & $5 / 9$ & $9 / 11$ & $y(b r)$ & 9.34 & 3 & 98.7 & 39.58 & 98.7 & 43.19 \\
\hline 10. Pagak II* & $11 / 9$ & $21 / 11$ & $\mathrm{~g}(\mathrm{br})$ & 9.30 & 2 & 99.3 & 35.44 & 90.7 & 46.08 \\
\hline \multicolumn{10}{|l|}{ Japanese soybeans } \\
\hline 11. Dwarf Hyuga & $29 / 8$ & $28 / 11$ & $y$ & 25.98 & 10 & 91.3 & 30.82 & 2.7 & 127.28 \\
\hline 12. Chiyohime* & $22 / 8$ & $16 / 11$ & $\mathrm{y}$ & 23.97 & 1 & 99.3 & 31.80 & 68.7 & 65.38 \\
\hline 13. Fukuyutaka* & $19 / 8$ & $9 / 11$ & $y$ & 28.28 & 9 & 100 & 31.50 & 93.3 & 38.75 \\
\hline 14. Hougyoku* & $25 / 8$ & $18 / 11$ & $y$ & 23.82 & 2 & 98.4 & 29.26 & 78.7 & 55.49 \\
\hline 15. Akisengoku* & $26 / 8$ & $21 / 11$ & $y$ & 17.92 & 4 & 98.7 & 35.03 & 60.7 & 82.85 \\
\hline 16. Tamahomare* & $10 / 8$ & $30 / 10$ & $\mathrm{y}$ & 25.33 & 9 & 98.7 & 33.97 & 62.7 & 77.22 \\
\hline \multicolumn{10}{|c|}{ American soybeans } \\
\hline 17. Clark $^{-} 63^{*}$ & $9 / 8$ & $18 / 10$ & Y & 18.24 & 35 & 66.7 & 31.43 & 51.3 & 64.40 \\
\hline 18. Wabash* & $9 / 8$ & $12 / 10$ & Y & 15.17 & 27 & 64.0 & 37.41 & 52.0 & 44.51 \\
\hline 19. Viking* & $9 / 8$ & $9 / 10$ & Y & 15.49 & 34 & 66.0 & 38.36 & 73.7 & 50.69 \\
\hline 20. Lee* & $16 / 8$ & $12 / 11$ & $\mathrm{Y}$ & 16.06 & 1 & 98.7 & 35.98 & 98.7 & 35.55 \\
\hline 21. Kent* & $9 / 8$ & $6 / 11$ & $\mathrm{y}$ & 18.23 & 53 & 96.0 & 039.36 & 56.0 & 58.25 \\
\hline 22. Burdete $-19^{*}$ & $16 / 8$ & $16 / 10$ & $\mathrm{~b}$ & 16.54 & 4 & 88.0 & 22.05 & 93.3 & 33.12 \\
\hline 23.Southern Prolific* & $19 / 8$ & $30 / 10$ & $\mathrm{~b}$ & 5.68 & 0 & 96.7 & 44.06 & 93.3 & 41.89 \\
\hline 23. $\mathrm{L}-12 / 9^{*}$ & $3 / 9$ & $29 / 11$ & $\mathrm{~b}$ & 5.77 & 3 & 96.7 & 39.64 & 56.6 & 93.29 \\
\hline 25. Yougold ${ }^{*}$ & $9 / 8$ & $16 / 10$ & $\mathrm{y}$ & 22.07 & 53 & 76.0 & 30.42 & 91.3 & 47.77 \\
\hline 26. $\mathrm{PK}-8-53^{*}$ & $16 / 8$ & $24 / 10$ & $\mathrm{~b}$ & 7.45 & 0 & 92.0 & 43.42 & 96.7 & 45.49 \\
\hline 27. Hood* & $10 / 8$ & $18 / 10$ & $\mathrm{Y}$ & 16.79 & 6 & 86.7 & 37.87 & 96.0 & 40.19 \\
\hline 28. Hill* & $29 / 8$ & $18 / 10$ & $y-g$ & 15.45 & 1 & 92.7 & 35.73 & 82.7 & 48.93 \\
\hline $29 . S-100^{*}$ & $9 / 8$ & $16 / 10$ & $\mathrm{Y}^{\circ}$ & 13.00 & 16 & 94.7 & 34.09 & 48.0 & 88.93 \\
\hline 30. Nonsemond & $10 / 8$ & $16 / 10$ & $\mathrm{y}(\mathrm{br})$ & 19.31 & 71 & 93.3 & 34.93 & 32.0 & 86.38 \\
\hline 31. Ogden ${ }^{*}$ & $16 / 8$ & $6 / 11$ & $\mathrm{~g}$ & 21.14 & 62 & 93.3 & 33.86 & 88.0 & 45.34 \\
\hline 32.Akuton Huji & $16 / 8$ & $30 / 10$ & $\begin{array}{l}\text { S } \\
Y\end{array}$ & 38.34 & 66 & 93.3 & 36.90 & 48.7 & 95.71 \\
\hline 33. Improved Pelican* & $3 / 9$ & $18 / 11$ & $y-g$ & 13.39 & 0 & 100 & 31.85 & 96.0 & 33.78 \\
\hline 34. H-10 & $16 / 8$ & $16 / 10$ & $Y$ & 23.78 & 88 & 92.7 & 36.26 & 56.0 & 67.08 \\
\hline 35. H-32 & $26 / 8$ & $2 / 11$ & Y & 13.45 & 0 & 95.3 & 40.43 & 88.7 & 55.83 \\
\hline 36. $\mathrm{H}-45$ & $22 / 8$ & $16 / 11$ & Y & 21.89 & 20 & 91.3 & 41.27 & 25.3 & 109.67 \\
\hline 37. H-30 & $22 / 8$ & $14 / 11$ & Y & 16.33 & 0 & 98.7 & 33.26 & 98.7 & 48.25 \\
\hline 38. L-4 & $22 / 8$ & $24 / 10$ & Y & 5.59 & 0 & 94.7 & 61.64 & 66.0 & 60.49 \\
\hline
\end{tabular}

1) Assessed by 6 days of accelerated ageing at $40^{\circ} \mathrm{C}, 100 \% \mathrm{RH}$.

2) Seed colour : y, yellow; b, black; g, green ; y-g, yellowish-green ; $($ (br), yellow or yellow and brown motley; $\mathrm{g}(\mathrm{br})$, green or green and brown motley; $\mathrm{yg}(\mathrm{br})$, green, or yellow or green and brown motley

3) 28 cultivars with' mark were used in experiment of Table 2. 
Table 2. Electrical conductivity and germination performance of acceleratedly aged $\left(40^{\circ} \mathrm{C}\right.$, $100 \% \mathrm{RH}$ ) soybean seeds of 28 cultivars produced in 1983."

\begin{tabular}{cccccc}
\hline \multirow{2}{*}{$\begin{array}{l}\text { Seed quality } \\
\text { parameter }\end{array}$} & \multicolumn{5}{c}{ Period of accelerated ageing } \\
\cline { 2 - 5 } & 0 day & 4 days & 6 days & 7 days & 8 days \\
\hline EC $(\mu \mathrm{S} / \mathrm{cm} / \mathrm{g})$ & 35.5 & 36.4 & 52.6 & 83.7 & 114.4 \\
& $(4.5)$ & $(6.4)$ & $(16.5)$ & $(32.3)$ & $(43.8)$ \\
$\mathrm{StG}(\%)$ & 92.7 & 94.3 & 81.5 & 14.1 & 1.6 \\
& $(10.7)$ & $(6.0$ & $(17.1)$ & $(21.2)$ & $(5.2)$ \\
GR $(\% /$ day $)$ & 25.8 & 28.6 & 24.5 & 3.6 & 0.4 \\
& $(5.2)$ & $(2.9)$ & $(6.7)$ & $(6.2)$ & $(1.4)$ \\
MGP $(\%)$ & 99.2 & 99.3 & 95.3 & 43.9 & 18.9 \\
GC $(\%)$ & $(1.7)$ & $(1.3)$ & $(6.5)$ & $(33.4$ & $(23.3)$ \\
& 98.1 & 98.4 & 91.3 & 26.2 & 7.8 \\
Abn $(\%)$ & $(3.4)$ & $(1.9)$ & $(11.0)$ & $(29.9)$ & $(18.6)$ \\
Dead $(\%)$ & 7.2 & 6.0 & 14.3 & 45.6 & 36.7 \\
& $(10.6)$ & $(6.1)$ & $(13.1)$ & $(24.3)$ & $(28.3)$ \\
& 0.2 & 0.2 & 4.2 & 40.2 & 61.4 \\
& $(0.5)$ & $(0.5)$ & $(6.6)$ & $(30.5)$ & $(30.9)$ \\
\hline
\end{tabular}

1) Data in parentheses denote standard deviations.

effective to distinguish varietal differences in seed vigour based on EC and StG. The treatment also elicited high significant correlation between EC and germination performance as depicted in Table 3.

\section{Ranges of viability and vigour of resulting seeds}

There was a wide range of varietal differences in seed vigour though the difference on seed viability among cultivars was relatively narrow. Fig. 3 shows that whilst seed vigour in terms of $\mathrm{StG}$ ranged from 0 to $100 \%$, seed viability ranged from 60 to $100 \%$. Data on EC ranged from 32 to 132 and from 22 to $62 \mu \mathrm{S} / \mathrm{cm} / \mathrm{g}$ for seed vigour and seed viability, respectively. The extremely low range of seed viability in terms of StG was occupied by Clark-63, Wabash and Viking (Table 1). These cultivars were then omitted in further analysis on varietal differences in seed vigour because they might have suffered from unexpected bad condition. Interestingly, Indonesian cultivars possessed the highest seed vigour $(93.4 \pm 6.7 \%$ as $\mathrm{StG})$, followed by American $(72.2 \pm$ $23.0 \%$ as $\mathrm{StG})$ and Japanese $(61.1 \mathrm{t} 28.3 \%$ as $\mathrm{StG})$ cultivars.

3. Factors associated with varietal differences in seed vigour

Table 4 shows intercorrelation among factors in question. This table demonstrates that varietal differences in seed vigour in terms of StG significantly correlated with reproductive growth period, accumulative daily mean temperature and accumulative rainfall during this period, seed size and the occurrence of defective seed, but did not correlate with flowering and growth period. In terms of EC, seed vigour significantly correlated with reproductive growth period and seed size, but did not with the others. Further investigation by means of stepwise regression analysis resulted in 


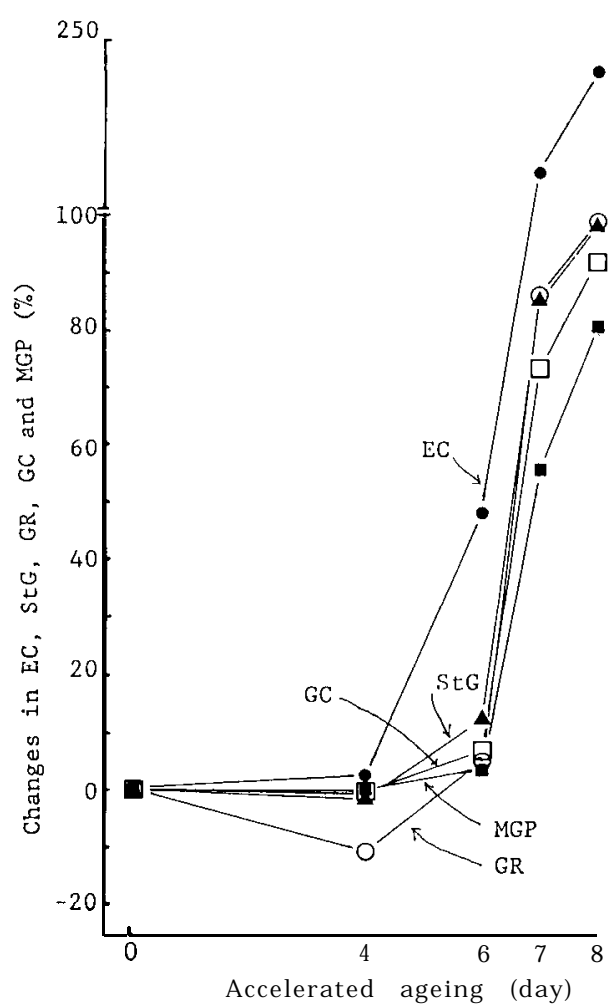

Fig. 2. Changes in seed vigour assessed by accelerated ageing at $40^{\circ} \mathrm{C}, 100 \% \mathrm{RH}$ (Increased change of EC and decreased changes of StG, GR, GC and MGP $; n=28$ cultivars).

a predominant association of seed size with varietal differences in seed vigour in terms of $\mathrm{StG}$. In terms of EC, however, seed vigour was particularly affected by reproductive growth period and the occurrence of defective seed. Their regression equations are presented in Table 5. For condensation, we present merely the relationship between seed vigour in terms of StG and seed size in Fig. 4. Table 5 and Fig. 4 show that the smaller the seed size, the higher the resulting seed vigour would be. In parallel, the longer the reproductive growth period and, coincidently, the more the occurrence of defective seed, the higher the EC would be, indicating the lower the resulting seed vigour (Table 5).

It seemed that the most vigorous seed possessed by Indonesian soybeans might have benefited from their small seed size. Their average 100-seed weight was $8.81 \pm$ $0.88 \mathrm{~g}$ compared to $15.80 \pm 6.25 \mathrm{~g}$ of American and $24.22 \mathrm{k} 3.18 \mathrm{~g}$ of Japanese. Paschal and Ellis (1978) found that many of soybean genotypes with superior seed quality were originated from Southeast Asia, and noted that seed size significantly negatively correlated with field emergence. The tendency of higher storability of small-seeded genotypes was also reported by Wien and Kueneman (1981), Minor and Paschal (1982) and Dassou and Kueneman (1984). Likewise in the present study, Indonesian soybeans 

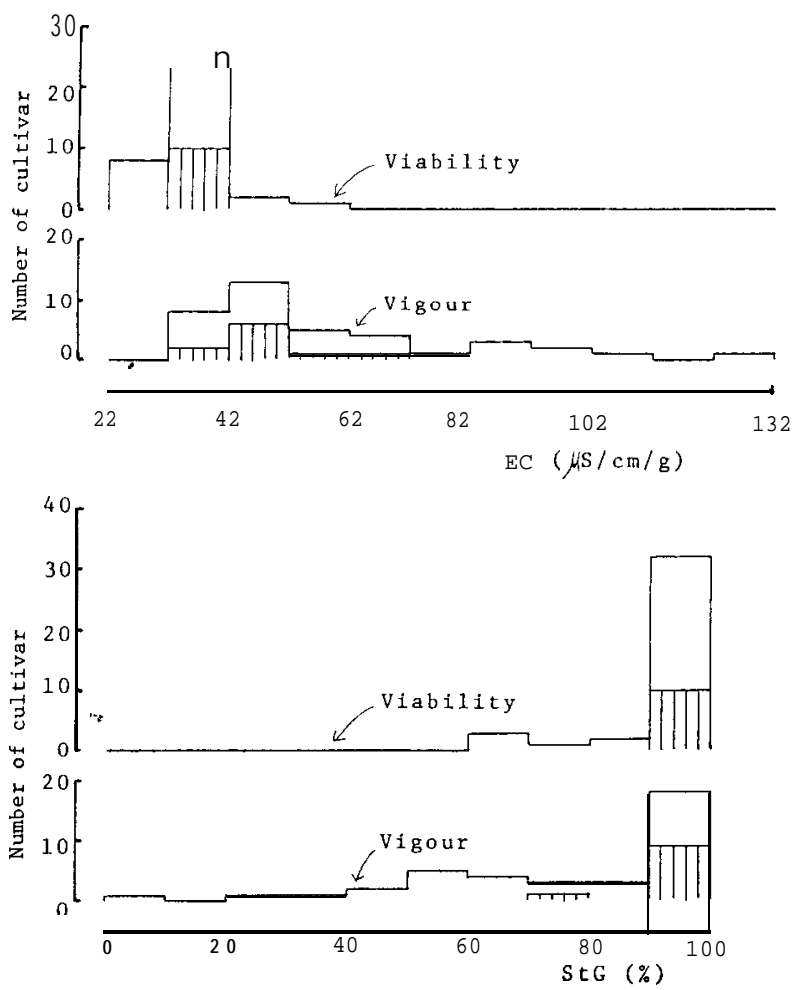

Fig. 3. Distribution of seed viability and vigour in terms of StG and EC (Vertical bars indicate to which Indonesian soybeans belonged).

Table 3. Correlation coefficients $(r)$ between electrical conductivity and germination performance of acceleratedly aged $\left(40^{\circ} \mathrm{C}, 100 \% \mathrm{RH}\right)$ soybean seeds of 28 cultivars. $^{1)}$

\begin{tabular}{ccccccc}
\hline \multirow{2}{*}{$\begin{array}{c}\text { Germination } \\
\text { performance }\end{array}$} & \multicolumn{5}{c}{$\mathrm{r}$ value at each period of accelerated ageing } \\
\cline { 2 - 7 } & 0 day & 4 days & 6 days & 7 days & 8 days & Overall \\
\hline StG & 0.130 & 0.063 & $-0.774^{* *}$ & $-0.449^{*}$ & -0.342 & $-0.774^{* *}$ \\
GR & $0.417^{*}$ & $0.510^{* *}$ & $-0.728^{* *}$ & $-0.406^{*}$ & -0.337 & $-0.744^{* *}$ \\
MGP & $0.451^{*}$ & -0.318 & $-0.899^{* *}$ & $-0.761^{* *}$ & $-0.620^{* *}$ & $-0.861^{* *}$ \\
GC & $0.613^{* *}$ & -0.085 & $-0.926^{* *}$ & $-0.566^{* *}$ & $-0.402^{*}$ & $-0.796^{* *}$ \\
Abn & -0.105 & -0.080 & $0.556^{* *}$ & $-0.738^{* *}$ & $-0.874^{* *}$ & 0.129 \\
Dead & -0.280 & 0.068 & $0.903^{* *}$ & $0.902^{* *}$ & $0.872^{* *}$ & $0.938^{* *}$ \\
\hline
\end{tabular}

I) Levels of significance were $5 \%\left({ }^{*}\right)$ and I $\%\left(^{* *}\right)$

were identified as the top genotypes possessing this characteristics (Dassou and Kueneman, 1984).

Lesser occurrence of defective seed in Indonesian soybeans $(0.7 \pm 1.0 \%)$ than in American $(24.5 \mathrm{k} 27.9 \%)$ and Japanese $(5.8 \pm 3.6 \%)$ might have also contributed to high 
Table 4. Intercorrelation among seed viability as $\mathrm{StG}(\mathrm{A})$ and $\mathrm{EC}(\mathrm{B})$, seed vigour as StG $(C)$ and EC (D), flowering (E), growth period (F), reproductive growth period $(G)$, accumulative daily mean temperature $(\mathrm{H})$ and accumulative rainfall (I) during this period, seed size $(\mathrm{J})$ and the occurrence of defective seed $(\mathrm{K}) .^{1 \text { ' }}$

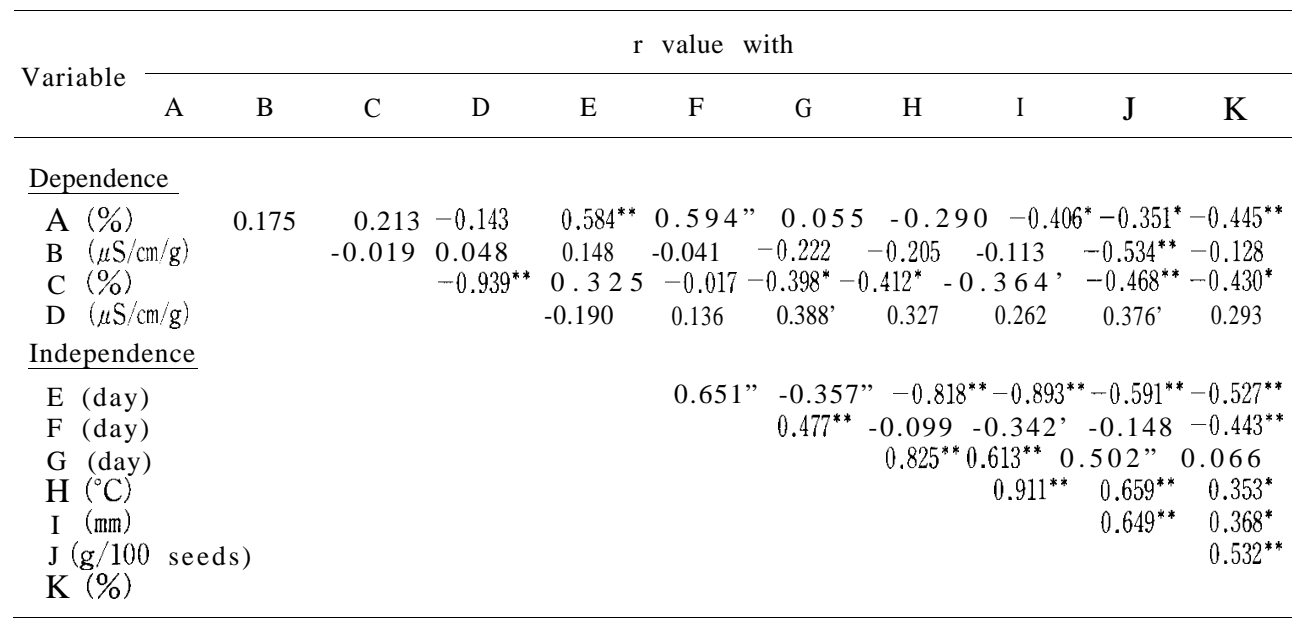

1) Numbers of cultivars were 35 ; levels of significant were $5 \%(*)$ and $1 \%\left({ }^{* *}\right)$

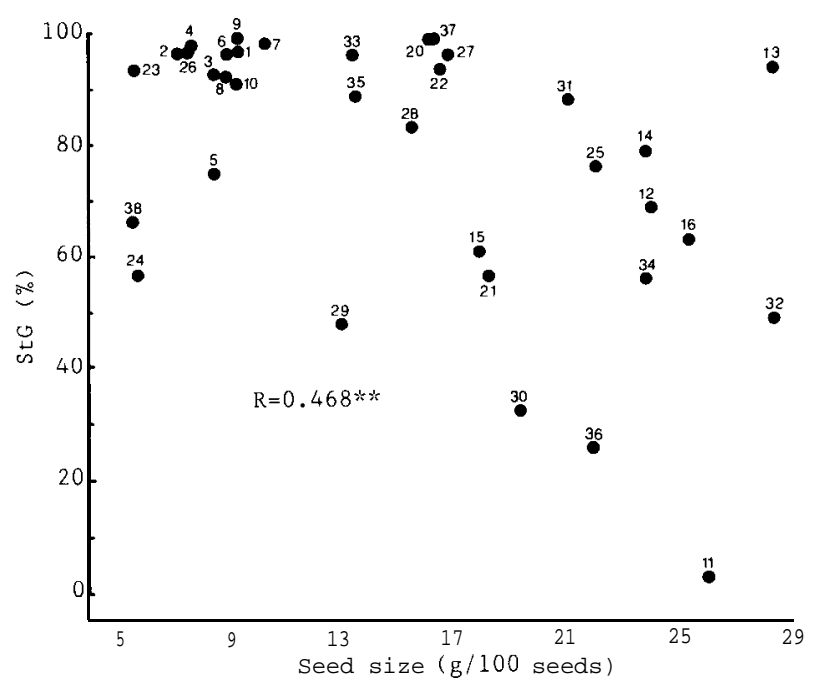

Fig. 4. Relationship between seed vigour in terms of $\mathrm{StG}$ and seed size.

seed vigour of Indonesian soybeans. Luedders and Burris (1979) observed that broken seed coat reduced laboratory germination and field emergence of soybean seeds, and positively correlated with the occurrence of abnormal seedling. More recently, Burchett et al. (1985) observed inferior viability and vigour of etched seeds to nonetched ones after subjecting to dropping and preconditioning at different moisture equilibria or temperature.

Further, the reproductive growth period of Indonesian soybeans was the shortest 
Table 5. Relationship between seed vigour as $\mathrm{StG}(\mathrm{C})$ and seed size $(\mathrm{J})$, and between seed vigour as EC (D) and reproductive growth period(F) and the occurrence of defective seed $(\mathrm{K}){ }^{11}$

\begin{tabular}{cc} 
Regression & Multiple correlation \\
\hline $\mathrm{C}=102.072-1.612(\mathrm{~J})$ & 0.468 \\
$\mathrm{D}=-1.139+0.779(\mathrm{~F})+0.252(\mathrm{~K})$ & 0.471 \\
\hline
\end{tabular}

1) Levels of significant were $1 \%$ for $\mathrm{C}$ and $5 \%$ for $\mathrm{D}$, respectively.

(63.8 \pm 4.7 days ) compared to American (71.7f10.3 days) and Japanese ( $85.3 \pm 3.3$ days). As reproductive growth period was closely related to seed filling period (Reicosky et al., 1982), it seemed that the short reproductive growth period characterized by Indonesian soybeans have contributed to less exposure of their seeds to unfavourable environment during their development and, especially, maturation. A significant positive correlation between EC as seed vigour and reproductive growth period (Table 4) confirmed the less damaging effect of short reproductive growth period to resulting seed vigour. Accordingly, Indonesian soybeans had the lowest EC as seed vigour $(47.23 \pm 9.72 \mu \mathrm{S} / \mathrm{cm} / \mathrm{g})$ compared to that of Japanese $(73.95 \pm 30.25 \mu \mathrm{S} / \mathrm{cm} / \mathrm{g})$ and American $(59.79 \mathrm{f} 22.96 \mu \mathrm{S} / \mathrm{cm} / \mathrm{g}$ ). Calculating data of summer soybeans presented by Hara and Ohba (1978), we found negative correlation between reproductive growth period and field emergence $\left(\mathrm{r}=-0.967^{* *}\right)$. Igita and Iwata (1977) also reported negative correlation between laboratory emergence of 82 summer soybean cultivars and their reproductive growth period $\left(\mathrm{r}=-0.618^{*} *\right)$ and accumulative daily mean temperature during this period $(\mathrm{r}=-0.580 " *)$.

The existence of intercorrelation among the seed vigour in terms of $\mathrm{StG}$, especially, seed size, the occurrence of defective seed, reproductive growth period, accumulative daily mean temperature and accumulative rainfall during this period (Table 4) indicated that the weathering damage by high temperature and much rainfall during reproductive growth period was coincident with an increase in the occurrence of defective seed. The fact that small-seeded genotypes contained less defective seeds and high vigour seed than large-seeded genotypes seemed to indicate that the smallseeded genotypes escaped from weathering damage which could occur during reproductive growth period. Results presented in Table 4 supported this, whereas significant positive correlation was found between seed vigour in terms of EC and seed size, suggesting (Parrish and Leopold, 1978) that small-seeded genotypes experienced lesser membrane damage than large-seeded ones. Whether or not its mechanism be attributable to different pattern in their physiological change during seed desiccation in the field will be the subject of further investigation.

Parallel to the that of Paschal and Ellis (1978) who reported no significant correlation between growth period and field emergence, the present report shows no significant correlation between growth period and seed vigour in terms of both StG and EC (Table 4). However, this lack of correlation was not without meaning. Fig. 5 shows that the average seed vigour of cultivars harvested from 1 to 10 November (middle autumn) was higher than those harvested before (early autumn) or after (late autumn) this period. The average of daily mean temperature and total rainfall during the middle autumn were $15^{\circ} \mathrm{C}$ and $5.5 \mathrm{~mm}$, respectively. And it indicates that the seeds 

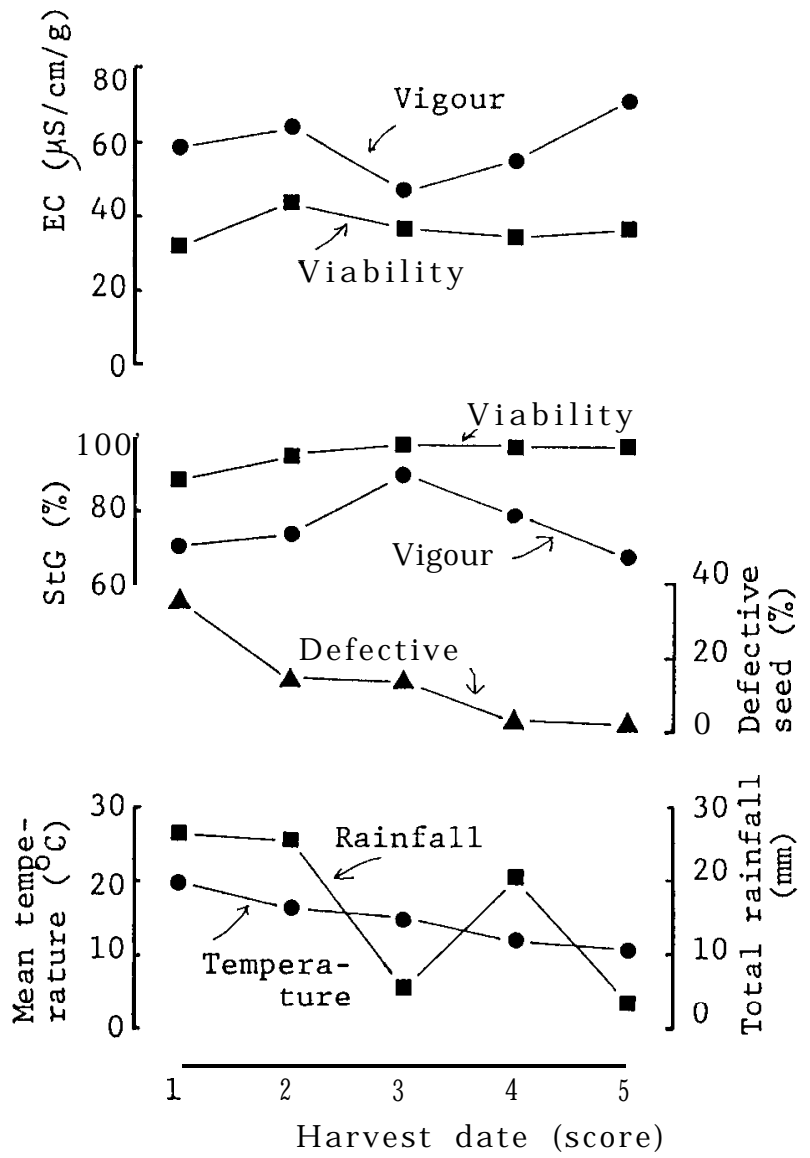

Fig. 5. Relationship among seed viability and seed vigour in terms of EC and StG, the occurrence of defective seed and environmental temperature and rainfall during harvest (Time score :1, 11-20 October ; 2, 20-31 October ; 3, l-10 November ; 4, 11-20 November ;5, 21-30 November ; $\mathrm{n}$ at 1, 2, 3, 4 and 5 were 7, 5.9, 7 and 7, respectively).

harvested in that period have matured in appropriate environmental condition, resulting in less weathering damage at postphysiological maturity. The seeds of cultivars harvested at the early autumn, however, matured in the conditions of high daily mean temperature and much total rainfall, resulted in lower seed vigour, Further, the seeds of those harvested from 11 to 20 November seemed to have suffered from much total rainfall in spite of rather suitable daily mean temperature. On the other hand, the seeds of those harvested from 21 to 30 November suffered from such a low environmental temperature that resulted in lower seed vigour. The occurrence of defective seed followed the changes of daily mean temperature and seemed to contribute to lower seed viability and vigour of those harvested at the early autumn. Differences in the factors associated with varietal differences in seed vigour in terms of StG and EC as presented in Table 5 warrant further investigation especially regarding the existen- 
Table 6. Comparison of seed vigour in the 7 groups of cultivars with the similar characteristics on some important traits associated with seed vigour.

\begin{tabular}{|c|c|c|c|c|c|c|c|c|c|c|}
\hline & Cultivar & $\begin{array}{c}\text { Flowering } \\
\text { date }\end{array}$ & $\begin{array}{l}\text { Harvest } \\
\text { date }\end{array}$ & $\begin{array}{l}\text { t RGP } \\
\text { (day) }\end{array}$ & $\begin{array}{l}\text { Acc. T } \\
\left({ }^{\circ} \mathrm{C}\right)\end{array}$ & $\begin{array}{c}\text { Acc. R } \\
\text { (mm) }\end{array}$ & $\begin{array}{c}100-\text { seed } \\
\text { weight } \\
(\mathrm{g})\end{array}$ & $\begin{array}{r}\text { Coat } \\
\text { defect } \\
(\%)\end{array}$ & $\begin{array}{c}\text { Coat } \\
\text { colour }^{1)}\end{array}$ & $\begin{array}{c}\text { Seed } \\
\text { vigour, } \\
\text { StG }(\%)\end{array}$ \\
\hline \multirow[t]{2}{*}{ A } & Fukuyutaka & $19 / 8$ & $9 / 11$ & 82 & 1824.1 & 444.5 & 28.28 & 9 & $\mathrm{y}$ & 93.3 \\
\hline & Akuton Huji & $16 / 8$ & $30 / 10$ & 75 & 1750.0 & 448.5 & 28.34 & 66 & $\mathrm{y}$ & 48.7 \\
\hline \multirow{2}{*}{ B } & Burdete - 19 & $16 / 8$ & $16 / 10$ & 61 & 1511.6 & 405.0 & 16.54 & 4 & b & 93.3 \\
\hline & $\mathrm{H}-10$ & $16 / 8$ & $16 / 10$ & 61 & 1511.6 & 405.0 & 23.78 & 88 & $\mathrm{y}$ & 56.0 \\
\hline \multirow[t]{3}{*}{$\mathrm{C}$} & Akisengoku & $26 / 8$ & $21 / 11$ & 86 & 1782.9 & 398.5 & 17.92 & 4 & Y & 60.7 \\
\hline & Pagak II & $11 / 9$ & $21 / 11$ & 71 & 1354.9 & 249.5 & 9.30 & 2 & $g(b r)$ & 90.7 \\
\hline & Presi Ulung I & $11 / 9$ & $21 / 11$ & 71 & 1354.9 & 249.5 & 10.31 & 0 & yg (br) & 98.0 \\
\hline \multirow[t]{2}{*}{ D } & Burdete -19 & $16 / 8$ & $16 / 10$ & 61 & 1511.6 & 405.0 & 16.54 & 4 & $\mathrm{~b}$ & 93.3 \\
\hline & Hill & $29 / 8$ & $18 / 10$ & 50 & 1203.4 & 318.0 & 15.45 & 1 & $y-g$ & 82.7 \\
\hline \multirow[t]{3}{*}{$\mathrm{E}$} & L - $12 / 9$ & $3 / 9$ & $29 / 11$ & 87 & 1644.7 & 340.0 & 5.77 & 3 & $\mathrm{~b}$ & 56.6 \\
\hline & P K - 8 - 53 & $16 / 8$ & $24 / 10$ & 69 & 1657.5 & 423.5 & 7.45 & 0 & $\mathrm{~b}$ & 96.7 \\
\hline & Southern Prolific & $19 / 8$ & $30 / 10$ & 72 & 1671.4 & 447.5 & 5.68 & 0 & $\mathrm{~b}$ & 93.3 \\
\hline \multirow{2}{*}{ F } & Dwarf Hyuga & $29 / 8$ & $28 / 11$ & 91 & 1769.9 & 390.5 & 25.98 & 10 & $\mathrm{y}$ & 2.7 \\
\hline & Tamahomare & $10 / 8$ & $30 / 10$ & 81 & 1925.4 & 448.5 & 25.33 & 9 & $\mathrm{y}$ & 62.7 \\
\hline \multirow[t]{2}{*}{ G } & Yougold & $9 / 8$ & $16 / 10$ & 68 & 1716.2 & 405.0 & 22.07 & 53 & $\mathrm{y}$ & 91.3 \\
\hline & $\mathrm{s}-100$ & $9 / 8$ & $16 / 10$ & 68 & 1716.2 & 405.0 & 13.00 & 16 & Y & 48.0 \\
\hline
\end{tabular}

1) Seed coat colour: y, yellow; b, black; y g, yellowish-green; $g(b r)$, green or green and brown motley; yg (br), yellow, green, or yellow or green and brown motley.

ce of defective seed. Although present study did not classify the degree of seed coat defect such as its size or area, it might be possible that such classification made more clearly the kinds of factors associated to varietal differences in seed vigour. However, as far as the terminology of defective seed in the present study was concerned, i. e. merely the occurrence of visible defect on seed coat regardless of its size or area, it is reasonable that EC and StG had different predominantly associated factors. These were supported by the fact that both parameters of seed vigour was closely correlative $(\mathrm{r}=-0.939 * *$, Table 4) each other.

Furthermore, the existence of vigour differences among cultivars with about the same seed size (Fig. 4) implied a possible influence of other factor in or out of question. An analogy is considered for the existence of more vigorous seed in large-seeded genotypes or, oppositely, less vigorous seed in small-seeded ones. Extending the interest on other factor beyond seed size as constant independent variable, Table 6 presents alternative factors considered to contribute to varietal differences in seed vigour in terms of StG for condensation. In group A (yellow seed colour with about the same seed size) Fukuyutaka might have been benefited from lower occurrence of defective seed and more favourable environmental condition during maturation (Fig. 5), resulting in higher seed vigour than Akuton Huji, although the latter had lesser accumulative daily mean temperature. Seeds of Burdete-19 in group B (flowering and harvest dates were the same ) might have been benefited from smaller seed size, lesser occurrence of'defective seed and black seed coat colour that resulting in higher seed vigour than $\mathrm{H}-10$. In group $\mathrm{C}$ (harvested at the same date and had about the same low 


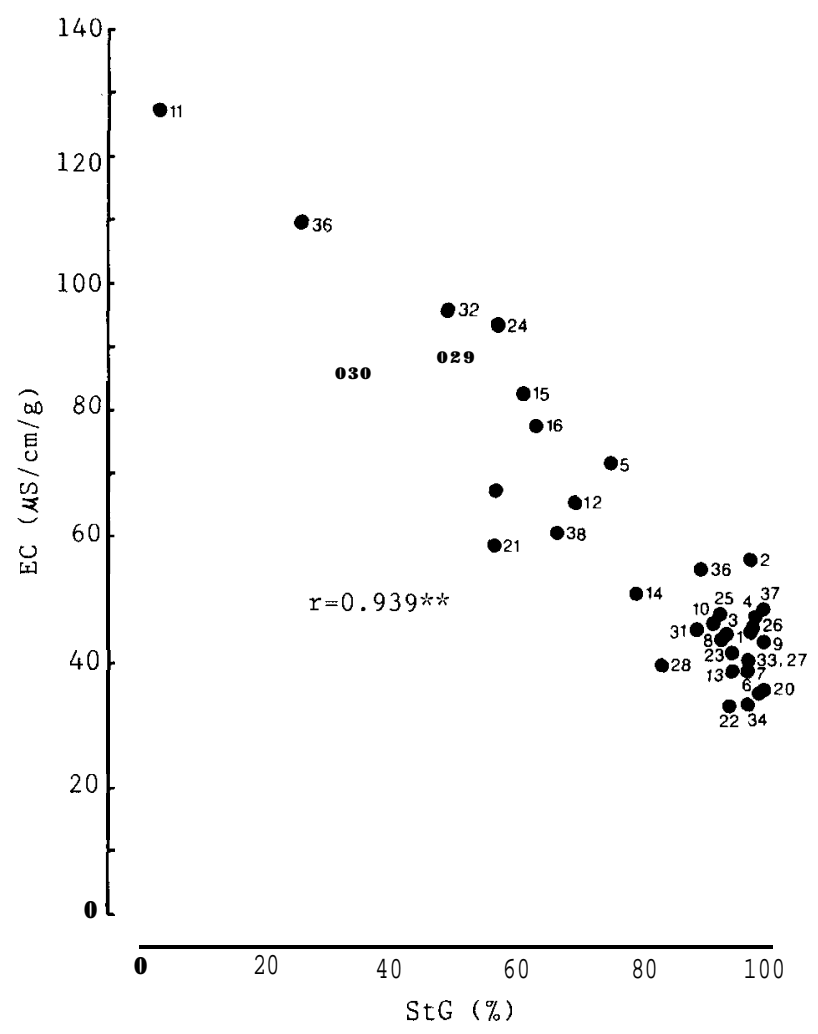

Fig. 6. Relationship between EC and $\mathrm{StG}$ as parameters of seed vigour (Assessed by 6 days of accelerated ageing at $\left.40^{\circ} \mathrm{C}, 100 \% \mathrm{RH}\right)$.

number of defective seeds) less seed vigour in Akisengoku might have been affected by the larger seed size and longer reproductive growth period than those in Pagak II and Presi Ulung I. In group D (seed size and defective seed were about the same) Burdete -19 might have been benefited from black seed coat colour compared to Hill resulting in more vigorous seed in the former, although the latter had shorter reproductive growth period. Hill, however, might have been benefited from its short reproductive growth period, less defective seed and small size seed, resulting in higher seed vigour than H-10 in group B, although their harvest dates were not much different. In group E (black seed colour with about the same seed size and number of defective seeds) $\mathrm{L}$ $-12 / 9$ might have suffered from cold injury resulting in its lower seed vigour than Southern Prolific and PK-8-53. Lower accumulative daily mean temperature and accumulative rainfall experienced by L-12/9 supported this phenomenon, although its reproductive growth period was longer than the other two cultivars. In group $\mathrm{F}$ (large-seeded genotypes with yellow seed coat colour and about the same number of defective seeds) Dwarf Hyuga was also suffered from cold injury, resulting its lower seed vigour than Tamahomare. Data in group $\mathrm{E}$ and $\mathrm{F}$ indicated that black seed coat colour and small size seed characterized by L-12/9 might have contributed to its higher resistance to cold injury than Dwarf Hyuga. In group $G$ (flowering and harvest dates 
were the same) other factor beyond those discussed above was possibly the reason for lower seed vigour of S-100 than Yougold. As shown here, S-100 had a smaller seed, lower occurrence of defective seed, the same seed colour and the same reproductive growth period. Whether or not seeds of Yougold have undergone lighter field weathering by difficulty of moisture migration through their pods needs further elucidation. However, varietal differences regarding this subject have been reported by Yaklich and Cregan (1981). If this was the case in the present study, the seeds of Yougold should have experienced less occurrence of wetting and drying at postphysiological maturity.

Likewise the present study, it was reported that many genotypes with black seed coat colour were superior in seed vigour to those with light colored seed coat. Dassou and Kueneman (1984) found that the former were more resistance to incubator weathering $\left(30^{\circ} \mathrm{C}, 90-95 \% \mathrm{RH}\right)$ than the latters. Among 35 genotypes tested they identified 9 of 16 genotypes with black seed coat colour as having resistance to field weathering and deterioration in storage. Of these, 6 genotypes were of Indonesian origin. Previously, Wien and Kueneman (1981) also identified that some genotypes with black seed coat colour had the highest storability among 50 genotypes tested. Starzinger and West (1982) observed the superior vigour of such genotype, assessed by storing the seeds in a $25^{\circ} \mathrm{C}, 100 \% \mathrm{RH}$ environment for 12 days, as was associated with less fungal activity on the seeds.

In conclusion, our data demonstrated that genotypical factors including reproductive growth period of mother plant, seed size, seed coat colour and the occurrence of defective seed controlled the vigour of resulting seeds. Excluding seed coat colour, the stepwise regression analysis resulted in predominant negative contribution of seed size on varietal differences in seed vigour in terms of StG. In terms of EC, however, the varietal differences in seed vigour were especially governed by the reproductive growth period of mother plant and the occurrence of defective seed. As far as other genotypical factors were almost at the same level, the genotypes with black seed coat colour were more vigorous than those with light seed coat colour. Present study warrants further investigation regarding the mechanism of seed resistance to field weathering in relation to its size and seed coat quality, and the influence of seed desiccation at postphysiological maturity on resulting seed vigour.

\section{REFERENCES}

Baskin, C. C. 1981 Accelerated ageing test. In "Handbook of vigour test methods", ed. by D. A. Perry. International Seed Testing Association, Zurich, pp 43-48

Burchett, C. A., W. T. Schapaugh, Jr., C. B. Overley and T. L. Walter 1985 Influence of etched seed coats and environmental conditions on soybean seed quality. Crop Sci., 25 : 655-660

Dassou, S and E. A. Kueneman 1984 Screening methodology for resistance to field weathering of soybean seed. Crop Sci., $24: 774-779$

Delouche, J. C. and C. C. Baskin 1973 Accelerated ageing techniques for predicting the relative storability of seed lots. Seed Sci. Technol., $1: 427-452$

Fehr, W. R. and C. E. Caviness 1977 Stages of soybean development. Coop. Serv., Agr. Home Econ. Exp. Sta., Iowa State Univ. Sci. Technol., pp 1-11

Hara, M. and T. Ohba 1978 Biological studies on germination disorders of summer soybean. Kyushu Branch Crop Sci. Soc. Japan, 45 : 95-97 (in Japanese) 
Igita, K. and I. Iwata 1977 Studies on the germination of summer soybean seeds. Kyushu Brunch Crop Sci. Soc. Japain, 44 : 76-79 (in Japanese)

ISTA 1976 International rules for seed testing. Seed Sci. Technol., 4 : 1-180

Luedders, V. D. and J. S. Burris 1979 Effect of broken seed coat on field emergence of soybeans. Agron. J., $71: 877-879$

Minor, H. C. and E. H. Paschal 1982 Variation in storability of soybeans under simulated tropical conditions. Seed Sci. Technol., $10: 131-139$

Mugnisjah, W. Q. and S. Nakamura 1984 Vigour of soybean seed produced from different nitrogen and phosphorus fertiliser application. Seed Sci. Technol., 12:475-482

Parrish, D. J. and A. C. Leopold 1978 On the mechanism of ageing in soybean seeds. Plant Physiol.,61 : 365-368

Paschal, E. H. and M. A. Ellis 1978 Variation in seed quality characteristics of tropically grown soybeans, Crop Sci., 18: 837-840

Potts, H. C., J. Duangpatra, W. G. Hairston and J. C. Delouche 1978 Some influences of hardseededness on soybean seed quality. Crop Sci., 18:221-224

Reicosky, D. A,, J. H. Orf and C. Poneleit 1982 Soybean germplasm evaluation for length of seed filling period. CropSci., 22: 319-322

Starzinger, E. K. and S. H. Weist 1982 An observation on the relationship of soybean seed coat colour to viability maintenance. Seed Sci. Technol., 10:301-305

TeKrony,D. M., D. B. Egli and A. D. Phillips 1980 Effect of field weathering on the viability and vigour of soybean seed. Agron.J., $72: 749-753$

Wien, H.C. and E. A. Kueneman 1981 Soybean seed deterioration in the tropics, II. Varietal differences and techniques for screening. Field Crop Res., 4: 123-132

Yaklich, R. W. and P. B. Cregan 1981 Moisture migration into soybean pods. Crop Sci., 21: 791793 